\section{Manned flight to Mars?}

Washington

Atrough the National Aeronautics and Space Administration (NASA) is officially keeping its distance, a dedicated group of space scientists within and without the agency is busily hatching plots for a manned space flight to Mars. The so-called "Mars Underground" has held several conferences to discuss ideas for the mission, which, members of this loose network of enthusiasts say, could be done for as little as $\$ 17,000$ million, and largely with

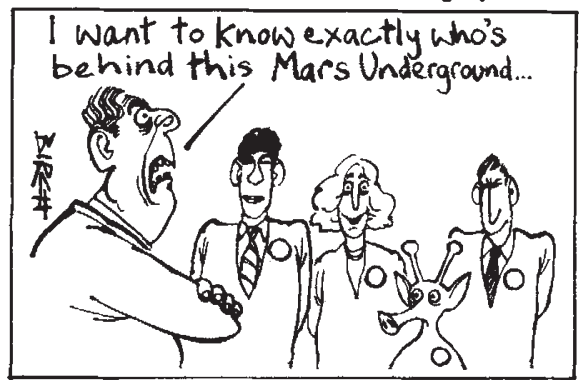

technology already available or being developed for NASA's space station.

The National Space Institute, a group of space buffs that sponsored two of the conferences, has even taken to distributing "Mars Underground"' lapel buttons to be "quickly flashed" at first sight of the NASA administrator, senators and congressmen.

The rise of the Mars underground has highlighted a growing rift between those who favour continued unmanned exploration of the planets - mainly planetary scientists concerned about getting the most data per dollar - and those pressing for a project that would rekindle the "thrill of exploration" that was the main dividend of the Apollo flights to the Moon. Carl Sagan has recently been trying to bridge the gap, conceding that a manned mission is not justifiable on a scientific basis alone, but urging it nonetheless in the form of a joint US-Soviet venture "on behalf of the entire human species".

NASA's current plans for Mars are limited to the unmanned Mars Geoscience/ Climatology Orbiter, scheduled for launch in 1990. Since the 1975 Viking 1 and 2 Mars landers, which raised many questions about the Martian surface, planetary scientists have been talking about follow-up missions involving a surface rover, a remotelypiloted vehicle and a return of a surface sample to the Earth.

To the extent that NASA is giving official attention to a manned Mars flight, it is in the context of advanced planning for the space station. Jesco von Puttkamer, NASA's programme manager for longrange studies - an office sometimes derisively described as NASA's division of daydreaming - says that a Mars flight is just one of five general categories of projects that an advanced space station could make possible; the others are low-

\section{Biotechnology}

earth-orbit instruments, commercial development of geosynchronous orbit, Solar System exploration with unmanned probes and establishment of a permanent lunar base. A space station would be a necessary jumping-off point for a Mars mission because of the sheer mass involved. Puttkamer says that a bare minimum weight for a Mars craft would be 2 million pounds; the huge Saturn V rocket built to launch Apollo to the Moon had a capacity of only 250,000 pounds. The space shuttle carries 65,000 pounds. Thus, assembly in Earth orbit is a necessity.

Puttkamer estimates the cost of the first Mars flight at \$50,000-65,000 million; even that figure assumes a larger shuttle and an advanced space station would already be available. And because the Earth and Mars are in a favourable orientation for a transit only every two years, a one-shot flight makes little sense. Nobody knows how much a continuing programme of Mars flights, including establishment of a Mars base, would eventually cost.

The more enthusiastic enthusiasts, such as the Planetary Society, put the costs much lower (\$17,000 million) and argue that new technology (such as aerobraking - using the atmospheres of Mars and the Earth to slow the craft down, instead of retrorockets) could cut fuel demand - and thus weight - considerably.

Some have also tried to raise the familiar Red Menace (which was good enough to get a man to the Moon) as a reason for pressing ahead. But according to a Congressional Research Service study by Marcia Smith, the Soviet capability argues against a serious effort on their part to put a man on Mars. The Soviets are apparently planning to send an unmanned probe to Mars's moon Phobos in 1986. But despite continued interest in Mars and a growing expertise in long-duration space flight, Soviet space hardware continues to be plagued with low reliability. Only one of the eight Soviet Mars probes has been an unequivocal success; the rest have missed the planet, crashed or failed to return data. And the Soviets have yet to try putting a man on the Moon. Stephen Budiansky

\title{
Agrigenetics forced to merge
}

\section{Washington}

THE acquisition earlier this year of Agrigenetics by Lubrizol Corporation may herald a new trend in the biotechnology industry. Things have come a long way since the heady days of summer 1983, when it seemed that any company offering expertise in the new technology could do no wrong in the eyes of investors. By early 1984, public offerings were getting a much cooler reception, making difficulties for some companies seeking development capital. Agrigenetics, based in Boulder, Colorado, had seemed one of the industry's brightest hopes, having an impressive array of research expertise. But a combination of high interest rates and a depressed agricultural products market, together with the decline of the high-technology securities market, eventually forced it to seek a merger with a much larger company.

Lubrizol is saying very little about its business plans, but does not intend to alter the direction of Agrigenetics' research, which may even be augmented. But there must also be some doubt whether Lubrizol, as sole owner, will want to renew the limited partnership deal it struck with Oppenheimers of New York in 1981 and which expires in 1986. That programme, which supports research worth $\$ 11$ million a year in 24 universities across the country, would be missed by many.

Analysts are cautious about generalizing too much from the Agrigenetics experience, since its business strategy was unusual from the start. Under chairman and founder, David Padwa, the company acquired seed companies to form a distribution network at the same time as expanding its research. Reliance on the agricultural products market may have increased its vulnerability with US agriculture in the doldrums. The research arm was spending $\$ 19$ million a year principally on developing new crop varieties by applying new techniques such as the microinjection of DNA into plant cells, the use of Ti plasmids and the exploitation of transposable elements. By having a distribution network already in place, the company hoped be able to steal a march on competitors when products of the new technology eventually reached the market.

Things began to go wrong in November 1983 , when the company decided to abandon a public share offering because of the deteriorating market. Looking instead at merger possibilities, Agrigenetics found Lubrizol, a manufacturer of special oils and oil additives, a likely mate. The company already owns 15 per cent of Genentech Inc., regarded by many as the Rolls-Royce of the biotechnology industry, and was seeking ways of using genetic engineering technology to produce improved vegetable oils.

Outstanding Agrigenetics shares were exchanged for $\mathbf{2 . 1}$ million Lubrizol shares worth $\$ 48$ million, and in addition Lubrizol took on Agrigenetics' debt of $\$ 60$ million. In the circumstances, Agrigenetics shareholders could have done much worse. Padwa resigned as chairman last month, but denies differences of opinion with the new owners over strategy, and may continue to serve occasionally as a consultant.
Tim Beardsley 